\title{
5. Whose governance, for whose good? The Laynhapuy Homelands Association and the neo-assimilationist turn in Indigenous policy
}

\section{Frances Morphy}

Originally, I set out to understand why the state has always seemed to be the enemy of 'people who move around' ... Efforts to permanently settle these mobile peoples ... seemed to be a perennial state project — perennial, in part, because it so seldom succeeded (Scott 1998:1).

\section{Introduction}

The Laynhapuy Homelands Association Incorporated (Laynha for short) is an Indigenous organisation that was incorporated under the Northern Territory's (NT) Associations Incorporation Act 1963 in 1984. ${ }^{1}$ Its headquarters are at Yirrkala in northeast Arnhem Land, from where it acts as the resource centre for a group of nearly 20 surrounding outstations or homeland settlements across a region of some $6500 \mathrm{~km}^{2}$ in extent. ${ }^{2}$ Yirrkala and the Laynha homelands are in the most easterly area of the Yolngu-speaking bloc (see Fig. 5.1), where varieties of Yolngu-matha are still the first languages of close to 100 per cent of the Aboriginal population. ${ }^{3}$ The 2006 Census recorded just under 6300 Indigenous people in

\footnotetext{
${ }^{1}$ This Act was superceded in 2004 by a new Associations Act (NT). Laynha is now incorporated under the new Act.

2 The terms 'outstation' and 'homeland', which are interchangeable in this context, are both problematic for different reasons. 'Outstation' carries the connotation that such places are peripheral to neighbouring larger settlements, which does not reflect the perspective of their inhabitants. 'Homeland' has become problematic because of a recent book (Hughes 2007) that deliberately conflates the meaning of this term in the Australian context with its meaning in the South African context, to support the spurious argument that Australian 'separatism' (to use the author's terminology) is analogous to the former apartheid regime in South Africa. The area given is the estimated extent of the Laynhapuy Indigenous Protected Area, the boundaries of which are not precisely coterminous with those of the Laynha service area (see Fig. 5.2).

${ }^{3}$ Yolngu is the term for (Aboriginal) person in the majority of Yolngu-matha dialects. Since the 1970s, it has become the most commonly used term to refer to the Yolngu-speaking peoples as a whole, but did not originally have that meaning. In the earlier anthropological literature the most well known alternatives are Murngin (Warner 1958), Wulamba (Berndt 1951, 1952, 1962) and Miwuyt (Shapiro 1981). The Yolngu-speaking people of northeast Arnhem Land are one of the most intensively studied Aboriginal societies in Australia. Roughly in chronological order according to when the authors undertook their fieldwork, major studies include: Warner (1958), Thomson (1949, 2006), Berndt (1951, 1952, 1962), Shapiro (1981), Peterson (1986), Williams (1986, 1987), Reid (1983), H. Morphy (1984, 1991, 2007), Keen (1994, 2003) and Macgowan (2007). The complex, asymmetrical Yolngu kinship system was the subject of the 'Murngin controversy' that occupied much space in anthropological journals in the 1960s (see Barnes 1967; Maddock 1970).
} 
discrete Indigenous communities in the Yolngu region of northeast Arnhem Land, and Laynha itself services a fluctuating population of between 600 and 800 people. The majority of the Laynha homeland settlements are on or near the coast. Inland, they tend to be near large rivers. They vary from large, permanently occupied settlements of well over 100 people to those that are only intermittently occupied and/or have small populations (fewer than 20 people). Several are inaccessible by road during the wet season, and all are inaccessible at the height of a 'big' wet. The most distant homelands are about three hours' drive from Yirrkala (during the dry). They mostly have all-year airstrips, although one or two do not.

Over the years since its incorporation, Laynha has become increasingly dependent on government - largely Commonwealth Government - grant funding. In 2006, some 87 per cent of its income was derived from government grants and one-quarter of its income from the Community Development Employment Projects (CDEP) program alone (including CDEP wages and associated costs) (Tallegalla Consultants 2006). Grant funding fuels its core service delivery functions of housing (building and maintenance), infrastructure and health, and its large CDEP program of around 300 participants. The Yirralka Rangers program, with over 40 rangers employed on CDEP wages, is also part of the organisation. It operates in the Laynhapuy Indigenous Protected Area (IPA) which was officially established in 2006 after several years of preparatory planning (Fig. 5.2). Until kava importation was summarily banned in June 2007 by government fiat, Laynha's major source of discretionary income was kava wholesaling and distribution. ${ }^{4}$ It also derived some income from civil works contracts such as road grading undertaken by its operations department, and from a small proportion of the royalty equivalents from the Alcan (now Rio Tinto) bauxite mining operation on the Gove Peninsula near Yirrkala. The separately incorporated air service, Layhna Air (or more formally Balamumu Mungurru Aviation Pty Ltd), runs a break-even charter service between Gove airport and the Laynha homelands.

\footnotetext{
4 The term 'discretionary' is applied here to income derived from other than government grant funding. This is the only portion of the organisation's funds that it is at liberty to spend or distribute entirely according to its members' priorities.
} 
Fig. 5.1 The Yolngu region

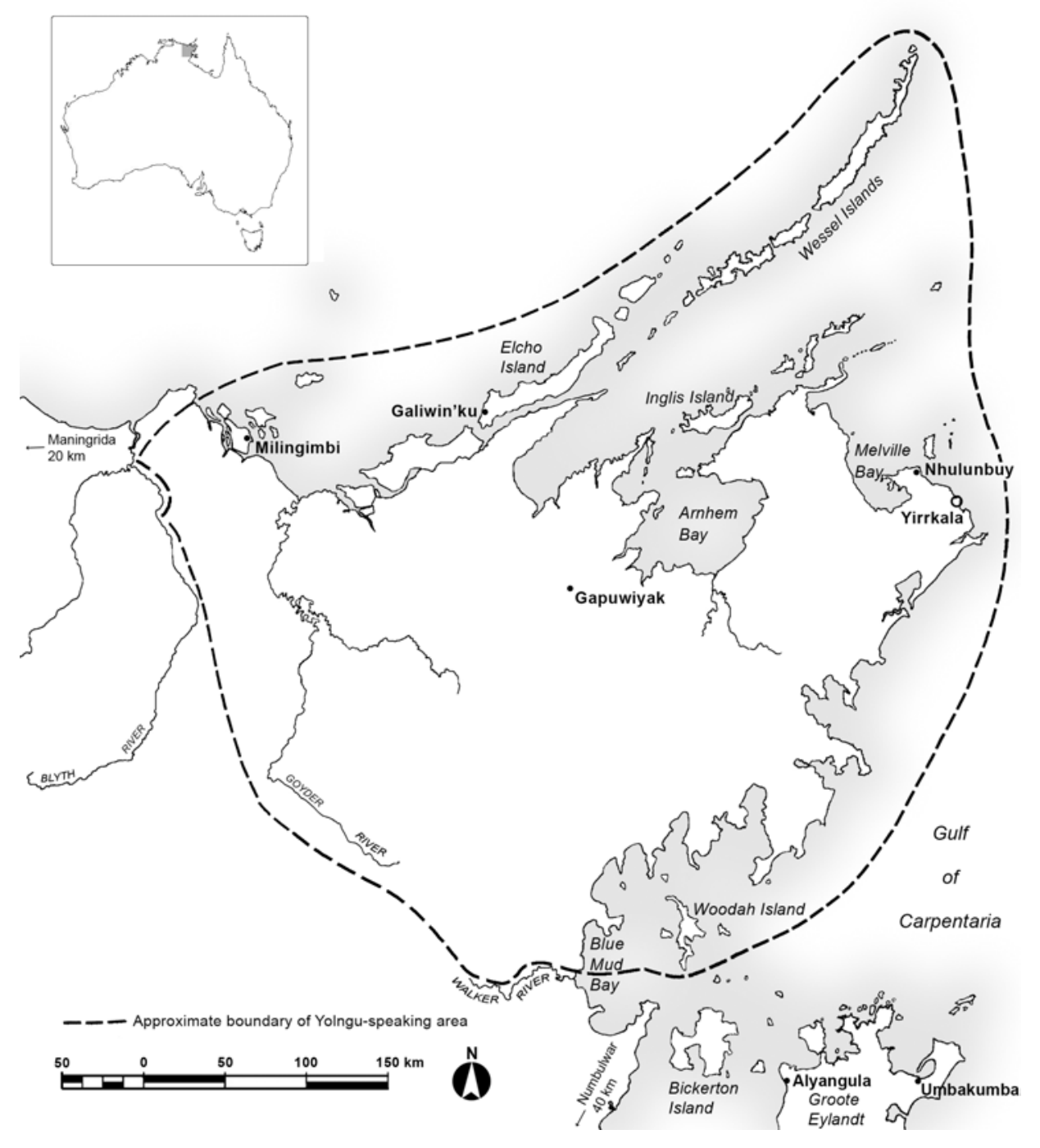


Fig. 5.2 The Laynhapuy Homelands Association homelands and the Laynhapuy Indigenous Protected Area

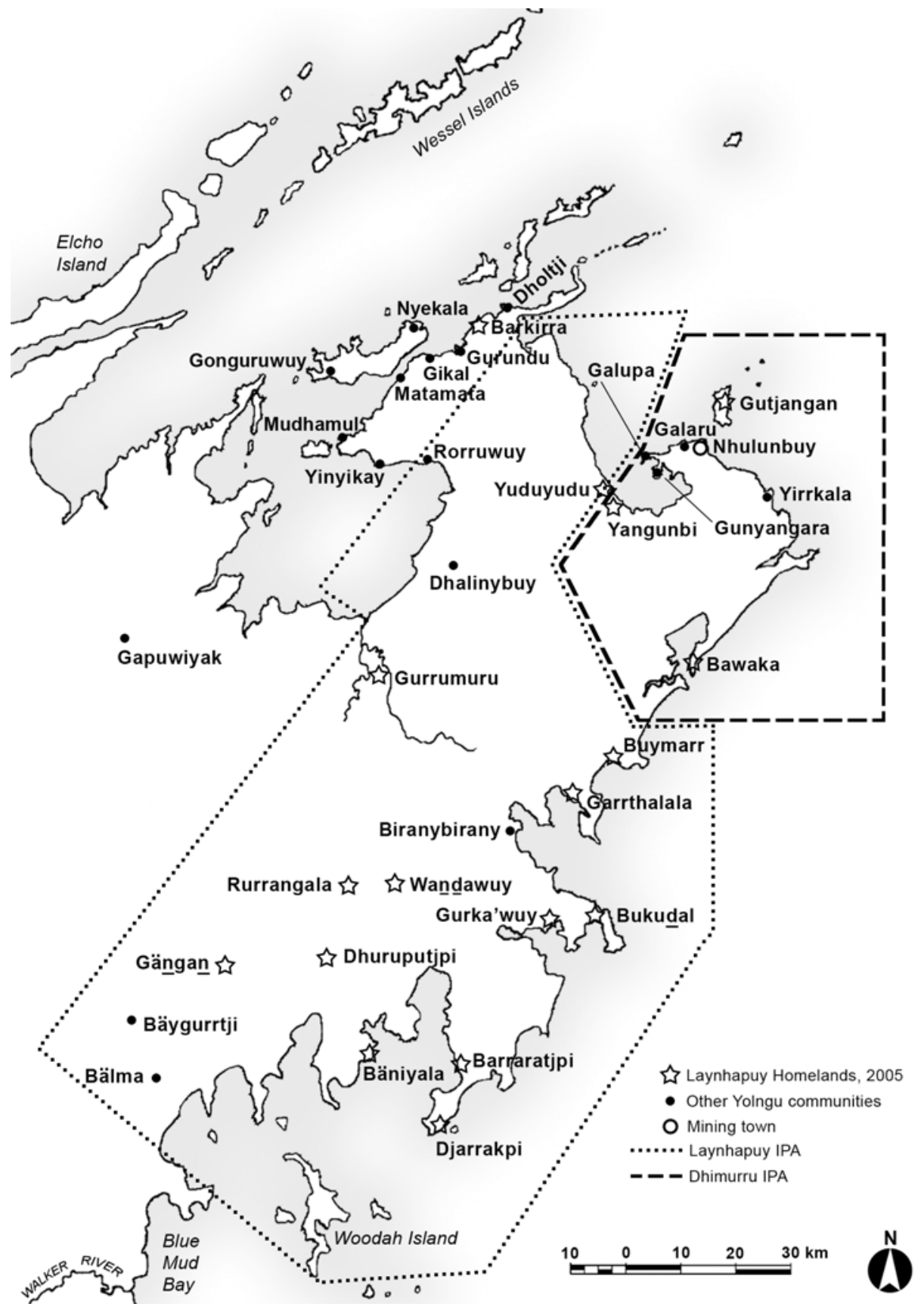


But Laynha did not start out that way. Its origins were in the Yolngu homelands movement of the 1970s, and it is necessary to understand these origins in order to understand certain characteristics of the contemporary organisation. The title of this chapter alludes to its major structuring theme: who 'owns' the organisation - its Yolngu members or its government paymasters? It will be argued that until recently it was not necessary for Yolngu to confront this question directly, and this had certain consequences for the way in which the governance of the organisation developed over the years.

There is currently abroad a mythical but influential view (epitomised in Hughes 2007) of 'homelands' people as passive victims of the misguided and failed policies of past governments. It is arguably true that Yolngu and other Indigenous Australians have been victimised through state neglect, but this does not automatically make them victims in any simple way. On the contrary, the Yolngu of the Laynha homelands have been able to maintain and elaborate a locally distinct domain of action and value precisely because the state's gaze was intermittent and largely directed elsewhere. Among those values are ones relating to governance - values that Yolngu bring with them into the organisation as members of its board and its staff.

\section{A colonial history?}

To understand the governance of Laynha it is necessary first to understand that the Yolngu and the encapsulating settler society have very different views of the relationship between the Yolngu and the state. The state views Yolngu unambiguously as 'citizens', albeit ones who have a unique historical relationship to the state. They are 'Aborigines' - descendants of the colonised original inhabitants of the continent. Colonisation, in the settler state view, is a fait accompli-Australia is a post-colonial, post-enlightenment liberal democracy, in which all citizens have both responsibilities and rights. How these rights and responsibilities are actively construed varies according to the political ideology currently prevailing in government circles, but the essential elements of the framework for governance are a given. The state view will be discussed in more detail below. It is necessary first to review, briefly, the local version of the colonial encounter and its impact on the Yolngu domain, as a background to elucidating the Yolngu view.

\section{The incursion of the pastoral frontier ${ }^{5}$}

The pastoral frontier, pushing from the south and west, ground to a halt at Florida Station on the southwestern fringes of the Yolngu region in 1885 (Berndt and Berndt 1954: 98-9). In the area around that station, Yolngu groups suffered depopulation in the 1890s, but the rest of the Yolngu region was substantially

\footnotetext{
5 This summary draws substantially on the account of contact history found in H. Morphy (2003).
} 
unaffected. There were sporadic incursions further into Yolngu country by prospecting expeditions (ibid. 93). During this period, Yolngu gained the reputation of being dangerous and unpredictable 'wild blacks' (Morphy and Morphy 1984). In the early 1900s, according to Yolngu oral history that is backed up in some cases by written accounts, a series of punitive expeditions were mounted into Yolngu territory. From the Yolngu perspective these expeditions were arbitrary acts of violence perpetrated by hostile invaders.

It was not until the 1930s that three interrelated events precipitated the 'pacification' of the Yolngu region (Berndt and Berndt 1954; Dewar 1992; Egan 1996). These were the killing of some Japanese pearlers at Caledon Bay in 1932, and of two white men, Fagan and Traynor, in 1933 in the vicinity of Woodah Island, and finally the spearing of Constable McColl on Woodah Island. ${ }^{6}$ In Yolngu oral history, all these killings happened as a result of the behaviour of the victims.

The reaction in the southern States at first was to send in a punitive expedition to avenge the deaths and 'teach the wild blacks a lesson'. Wiser council prevailed, however; the missionaries who were by now established on the fringes of Yolngu territory to the south and west and on Groote Eylandt, offered to intercede, and so too did the anthropologist Donald Thomson. ${ }^{7}$

\section{'Mission times'}

Methodist missions were established in the Yolngu area during the 1920s at Milingimbi, and then later in the 30s and 40s at Yirrkala and Elcho Island (Galiwin'ku). The Yolngu did not perceive this as an act of colonisation. Thomson reported to the Commonwealth Government in 1937 that Aborigines in Arnhem Land 'believe they are still living under their own laws, and that they have no reason to recognise a new regime has taken over their affairs' (cited in Attwood 2003: 116). And Williams (1987: 20) comments that '[f]rom a Yolngu perspective it was Mawalan, as head of the land-owning Rirratjingu clan, who granted permission to Chaseling, as agent of the "mission" to establish the station at Yirrkala [in 1935]'. The missionaries were few in number and came with peaceful intent, and early superintendents, such as Wilbur Chaseling at Yirrkala, showed respect for Yolngu culture and took a syncretic attitude to the introduction of Christianity that did not seek to eradicate the Yolngu belief system. ${ }^{8}$

\footnotetext{
${ }^{6}$ McColl was a member of the police expedition sent into the area from Roper Bar to investigate the killing of the Japanese.

7 Thomson never produced a major monograph on his fieldwork among the Yolngu, and his work did not have the impact that it merited within his lifetime. See H. Morphy (2002), and Nicolas Peterson's compilation of his most significant writings (Thomson 2006). The latter, the second edition of the work, contains many of Thomson's superb photographs of Yolngu life on country in the mid 1930s.

${ }^{8}$ The superb Yirrkala Church Panels, that once stood on either side of the altar in the church at Yirrkala and are now housed at Buku-Larrnggay Mulka, are a testament to the attitudes of the missionaries in this period. See Kleinert and Neale (2000: plates 31 and 32, opposite p. 70).
} 
The missionaries did seek to centralise the population in the mission settlements through the provision of rations and schooling for the children (the latter was valued by Yolngu from the outset), but there was no coercion or forced removal of people from their lands. Not all Yolngu went into the missions to live; some groups stayed out on their clan estates, coming into the mission from time to time for supplies or medical attention. Others lived at the missions most of the time, but returned regularly to their country, particularly during school holidays. Many members of the southern clans of the Blue Mud Bay area went south to Numbulwar (then Rose River) or to Umbakumba on Groote Eylandt rather than north to Yirrkala.

From the perspective of the senior Yolngu generations of today, this period, which lasted until the early 1960s, was something of a Golden Age. Interaction with outsiders, mediated through the missionaries, was sporadic and usually peaceful, and while sedenterisation on missions created some strains and tensions the Yolngu social fabric was not shattered, and the Yolngu were not dispossessed and alienated from their country.

The most senior living generation of today's Yolngu leaders spent their formative years in this era. Many of them, through the efforts of the missionaries, received a good western-style education; several went south or to Brisbane for further education. The Yolngu of this generation have never fully acceded to the proposition that their sovereignty over their clan estates has been eclipsed by the process of colonisation; they see themselves as encapsulated, but not colonised, as living in 'two worlds' (F. Morphy 2007b).

\section{Mining and land rights}

In the late 1950s, Yolngu became aware of prospecting activity on the Gove Peninsula, and discovered shortly afterwards that mining leases had been taken out over considerable areas of Yolngu land. There had been no consultation with Yolngu. Their response, in 1963, was to send a petition framed in bark to the Federal Parliament, demanding, among other things, the recognition of their rights in land and sea. It is significant that from the very beginning of the struggle against the coming of the mine the local clans whose land was affected received active support from the other Yolngu of the region.

The events that followed are well known and well documented, and will not be detailed here (see Attwood 2003; Wells 1982). The Yolngu were ultimately unsuccessful in their efforts to block the development of the mine and the building of the mining town of Nhulunbuy. Yolngu leaders asked for Nhulunbuy to be a dry area, foreseeing all too clearly what the effects of the introduction of alcohol would be, but in this too they were unsuccessful. Nevertheless, the Yolngu struggle to protect their rights was ultimately a significant factor in the 
advent of land rights and the passing of the Aboriginal Land Rights (Northern Territory) Act (1976 (Cth) (ALRA). The irony is not lost on the Yolngu.

\section{The homelands movement and the origins of Laynha}

The move out of Yirrkala and back to permanent settlements on the homelands was precipitated by the social trauma that followed the building of the mining town and the introduction of alcohol to the area. But it was also motivated by a positive desire to protect clan estates from further incursion, to demonstrate to outsiders that northeast Arnhem Land was not an uninhabited 'wilderness'. In the beginning, people received very little support-opinion among local missionaries, who had been very supportive in the struggle against the mine, was divided. With the logistic help of just a very few people, most notably the Fijian lay missionary Jonetani Rika, Yolngu groups began to go back to their country in 1971-72. At first they lived in bush shelters and had no reliable food supply apart from that obtained through hunting and gathering. Overland access was difficult - over a network of rough tracks that were impassable during the wet season - and there were very few vehicles. People cleared their airstrips by hand. ${ }^{9}$

This homelands movement was thus a Yolngu initiative (Morphy and Marika 2005: 1), and began before there was any official support from government for such movements. It predated the era of 'self-determination' ushered in by the first Whitlam Government, and it predated the ALRA. Subsequent policy settings certainly supported the movement both financially and logistically, but to suggest that it was a 'socialist experiment' perpetrated on Yolngu (see Hughes 2007) is a distortion of the historical record.

In the early 1970s, the Uniting Church ceded the administration of Yirrkala and its outstations to the Dhanbul Association-a Yolngu council that was incorporated under the NT's Associations Incorporation Act 1963. At first, the servicing of the homelands was part of Dhanbul's responsibility. As the homelands grew in number, the perception also grew among homelands people that their interests were regarded by Dhanbul as secondary to those of the clans who were the traditional owners of Yirrkala and the area covered by the mine. In 1984-85 Laynha was established as a separate association, also under the NT's Associations Act. The separate establishment of Marngarr, as the governing body of the settlement of Gunyangara (Ski Beach) on Gupa Gumatj clan land nearer to the mine's processing plant, soon followed.

\footnotetext{
${ }^{9}$ See Ian Dunlop's Narritjin at Djarrakpi (motion picture) 1980, Part 1, one of a series of films that he made for Film Australia's Yirrkala Film Project. Dunlop's Yirrkala series provides a unique documentary record of many aspects of homelands life from the beginning of the homelands movement in the 1970s through to the mid 1990s.
} 
In many ways, what was happening was a dissolution or weakening of the alliances between the groups who had joined forces to fight the Gove case, and who had been gathered together under the polity of the mission. The splits that occurred reflect the spheres of interest created by missionisation and the coming of the mine, lying, as it were, over the top of pre-existing, intra-Yolngu nodes and networks of political interaction. In the case of Laynha, an additional impetus to separate incorporation came from the Blue Mud Bay clans' involvement in the homelands movement, since they had never been a significant part of the Yirrkala mission polity.

The young adults who followed their parents back home and did most of the hard labour in the early days are now the senior generation living on the homelands. For them the homelands are the bastions of Yolngu identity, where people have the power to filter the influences of the outside world. They recognise that they are now inextricably linked economically to the wider society, but they wish to have control over the nature and intensity of those links. Today, they see the need for economic development on the homelands to provide meaningful employment that will keep the younger generations from drifting to the bigger settlements and the influences of the mining town. They are also keen to see improvements in the health, housing and infrastructure of their communities and in the education of their children.

\section{The Yolngu 'world'}

In writing of the theorisation of relationships between Aboriginal people and the state, and of understanding continuity and change in that context, Merlan (1998: 180-1) contrasts three views. She argues that both Sahlins (1993) and Cowlishaw (1988) have a 'vision of indigenous cultural production as autonomous', the former framing change as an adaptive process and the latter as opposition or resistance. She characterises her own theoretical position in terms of the intercultural: 'the contemporary Australian scene ... cannot be fundamentally understood in this way [in terms of autonomous production] ... That scene is not one of autonomy, but of still unequal, intercultural production'.

The Yolngu themselves (as might be predicted from the previous section, and from their espousal of the 'two worlds' view) would favour the Sahlins view, with perhaps a dash of Cowlishaw, particularly in relation to their response to the incursion of the mine. Yet another analytic framework (H. Morphy 2007) posits the relative autonomy of systems of cultural production, each with its own properties and trajectory through time. This approach privileges neither 'adaptation' nor 'resistance' as modes of interaction with other systems, and allows such interactions to have effects on a system and on its trajectory without compromising its relative autonomy. 
Such a model captures the Yolngu view and seems more relevant from an analytic point of view to the facts of the Yolngu case than a model that portrays everything as 'intercultural'. The relative lateness of the colonial incursion into northeast Arnhem Land, and its partial and predominantly peaceful nature, spared the Yolngu from the more devastating consequences of colonisation experienced by Aboriginal people in most other parts of the continent, including the area that is the focus of Merlan's analysis. It is possible to mount a cogent argument for the relative autonomy of the Yolngu system.

Where the Yolngu view and the analyst's view might diverge is in the analysis of the effects of interaction between the Yolngu system and that of the encapsulating settler state. The 'two worlds' view has been effectively unchallenged by the state until recently. In hindsight, however, it has proved to be a source of vulnerability as well as strength, for it has perhaps concealed from the Yolngu the extent to which their 'world' depends for its space to exist and follow its current trajectory upon institutions of the encapsulating state (Morphy and Morphy 2007). For more than a generation, two of the most important of these institutions - the fee simple status of Aboriginal land under ALRA and the CDEP program-had seemed permanent, and were taken-for-granted features of the social landscape. All this was to change between 2005 and 2007.

\section{Rom and gurrutu: the foundations of Yolngu governance}

The foundation of the Yolngu social system and system of governance is gurrutu - the complex networks of kinship that link individuals and groups to each other. Underlying gurrutu, and anchoring the human groups that are linked by gurrutu to their land and sea estates, is rom. Often translated as 'law', rom is a much more encompassing concept. It is nothing less than the Yolngu way of being, conceived as having been set down in the time of wangarr (creation) by beings who are still present in the landscape, and whose substance each Yolngu person shares through the conception spirit that enters their mother and gives life to the physical substance of the baby.

A person belongs to the bäpurru of their father. In one meaning of the term, bäpurru are the groups in which the ownership of land and sea estates is vested, and the meaning encompasses not just the living representatives of the group but also its spiritual essence located in the clan estate, the product of wangarr activity. Clan members are wänga-watangu ('place-belongs to' [people]; i.e. those to whom the place belongs, and who belong to the place) with respect to their clan's estates. In the anthropological literature, bäpurru are termed 'clans' (H. Morphy 1984, 1991, 2003; Williams 1986, 1987), 'patrifilial descent groups' (Keen 1994, 2003) or 'patri-groups' (Keen 2006), and Yolngu themselves often 
use the English word 'tribe' to describe them. ${ }^{10}$ The Yolngu universe is divided into two exogamous patrimoieties called Dhuwa and Yirritja. ${ }^{11}$ Each clan and its estates and creator wangarr beings belong either to one moiety or to the other. By definition then, clans are also exogamous.

In the Yolngu marriage system (see Fig. 5.3) a man marries his matrilateral cross cousin-his mother's mother's brother's daughter's daughter (MMBDD) (galay). A woman marries her patrilateral cross-cousin (dhuway). A man and his sister must therefore take spouses from different groups. The clans involved in the marriage of a man are: his mother's mother's clan (his märi), who bestow on him a mother-in-law (mukul rumaru) (his MMBD); his own clan; his mother's clan (his ngändi); and his wife's own clan (which may be the same clan as his own mother belongs to, but need not be). The marriage of the man's sister involves a different (but often overlapping) chain of linked clans.

Viewed over time, the Yolngu marriage system constructs long-term relationships of bestowal and marriage that link groups of both moieties. The relationship between a person and their mother's clan (of the opposite moiety) is some times referred to as yothu-yindi (child-mother). Just as a person is waku to his/her mother and her brother, so he/she stands in a waku relationship to his/her mother's (ngändi) clan. Waku have special responsibilities to their ngändi clan. In fulfilling these responsibilities they are termed djunggayarr (or djunggayi), often translated into English as 'manager' or 'caretaker' or sometimes 'policeman'. In essence, they have a duty of care to their mother's estate, and this involves helping - or sometimes ensuring that - the ngändi clan members look after their country properly, both in mundane and ceremonial contexts.

An equally significant relationship is constructed between two clans of the same moiety who stand in a relationship of märi (MM) and gutharra (DD) to one another, because over time the märi clan bestows mothers-in-law on members of the gutharra clan. ${ }^{12}$ This structure is illustrated in Fig. 5.4. The märi-gutharra connection between two clans is central to the Yolngu system of governance.

\footnotetext{
10 The differences in terminology reflect the authors' different conceptualisations of these groups. Bäpurru may also be used to refer to a set of clans linked ceremonially by the travels of particular wangarr beings, reflecting a Yolngu modelling of the social world that privileges connections over boundaries when considering the relationship between groups. Further discussion of this issue falls outside the scope of this chapter.

11 A patrimoiety is one in which a person inherits their membership from their father. An exogamous group is one that does not allow marriage between its members.

12 That is, a man bestows his daughter as mother-in-law, and therefore his daughter's daughter as wife, to his sister's daughter's son. A man calls both his mother's mother and her brother märi, and they call him (and his sisters) gutharra.
} 
Fig. 5.3 Kin relations in the Yolngu marriage bestowal system

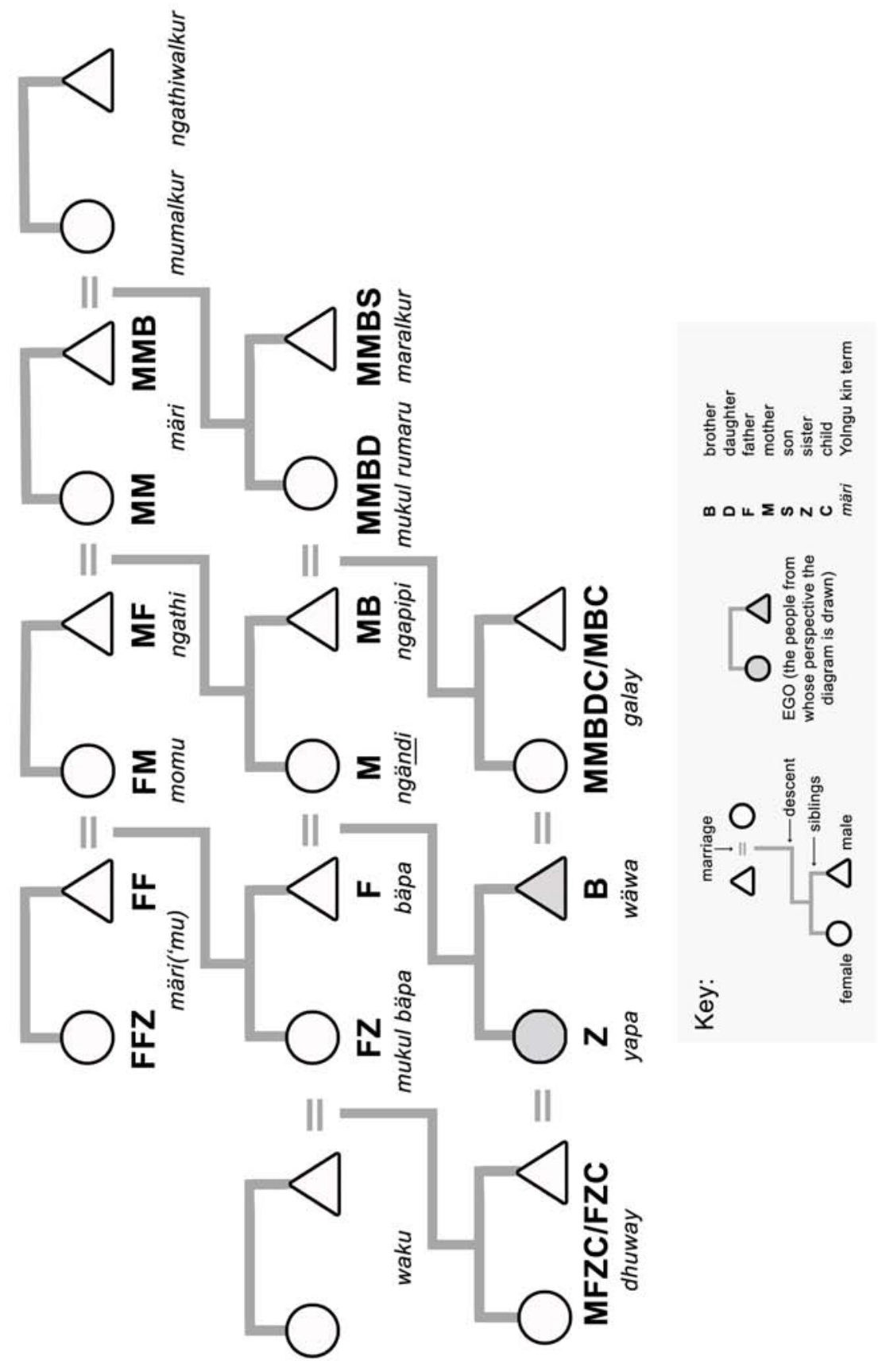


Fig. 5.4 The märi-gutharra and ngändi-waku relationships between clans, from the perspective of a Madarrpa sibling pair

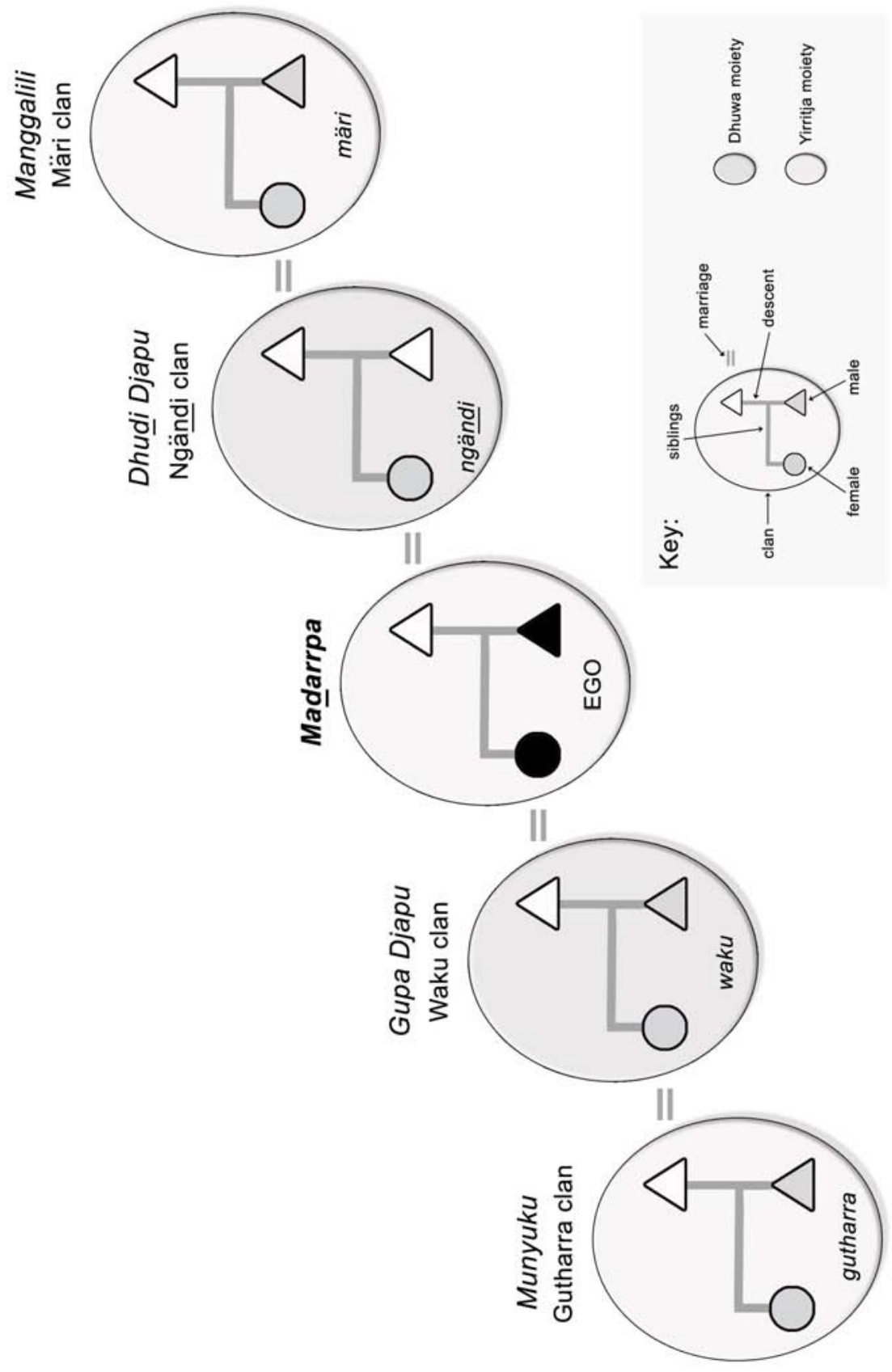


In the past, and to a considerable extent still in the present, most marriages tended to take place between members of geographically neighbouring clans, and so over time 'connubia' - that is, regional groupings of clans that are linked in sets of marriage relationships - tend to emerge. In the northern Blue Mud Bay area, for example, the Manggalili clan provides mothers-in-law to the Madarrpa clan, and the Madarrpa in turn provide mothers-in law to the Munyuku (see Fig. 5.4). The clans from which wives come (i.e. the clan into which the mother-in-law is married) are, for the Madarrpa, predominantly the Dhudi Djapu and the Marrakulu clans, and for the Munyuku, predominantly the Gupa Djapu. The Dhudi Djapu clan, in turn, provides mothers-in-law to the Gupa Djapu.

The existence of connubia is not merely statistical-they are not simply an emergent property of the local system of kinship and marriage. They are recognised by Yolngu as a social fact. Connubia are often associated with regional names. ${ }^{13}$ For example, the northern Blue Mud Bay clans are the Gindirrpuyngu 'people of the floodplains' or Djalkiripuyngu 'foot(print) people'. ${ }^{14}$ These cultural properties of connubia are a factor in their reproduction over time.

Connubia are nodal networks rather than bounded groups. Their networks intersect with those of other similarly constituted connubia. For example the märi for Manggalili are the Yarrwidi Gumatj, and this links Manggalili to the Laynhapuy connubium that is focused around Caledon Bay to the north. These networks of individuals may stretch out beyond the connubium in which other members of their clan are embedded. In the Blue Mud Bay area, for example, there is another märi-gutharra chain that links some members of the Madarrpa clan, through marriage, to groups on Groote Eylandt, and other individuals are linked to groups to the south and inland, again through their marriages.

Despite the challenges posed by colonisation and its aftermath, the underlying principles of the Yolngu gurrutu system are largely intact. As a system it can be said to exist in a state of relative autonomy: not untouched or uninfluenced by its contact with settler Australian society, but, nevertheless, with structures and systems of value that have their own trajectory. The system was always flexible and adaptive, and it has continued to be so in the face of the changes ensuing on the colonial process. The demography of small groups is rarely stable; some groups decline in number over time while others expand. The Yolngu system was flexible enough in the past to deal with such contingencies, and it had

\footnotetext{
13 The Yolngu naming of groups at various levels is an extremely complex issue. The pioneering (and most comprehensive) study is Schebeck (2001). Williams (1986: 57-74) also has an extended discussion of names and their meanings.

14 Djalkiri, ('foot', 'footprint') like many Yolngu terms for body parts, is entangled in a complex metaphorical universe (see also Tamisari 1998). It may also refer to an 'ancestral imprint on the landscape', and it is sometimes translated as 'foundation' — that is, 'the origin of law and identity'. In the name 'Djalkiripuyngu' it refers ostensibly to footprints in the mud of Blue Mud Bay, but may also carry the connotation that these groups are the 'foundation' people with respect to rom.
} 
mechanisms for succession when individual clan groups declined to a point where they could no longer partake fully in the system. In brief, if a clan becomes depleted or extinct a gutharra clan that shares the same wangarr inheritance will (ideally) first assume responsibility for looking after that clan's estate, and, if extinction follows, it will assume ownership of it (H. Morphy 2003). There is no reason to suppose that connubia were ever static entities with bounded memberships. Both political and demographic factors work over time to shift the nodal foci.

\section{Mobility in the midst of stability}

Since mission times, with sedentarisation, a certain fixing of connubia has been taking place. Today, they tend to be associated with groups of geographically contiguous homelands, situated on the clan estates of the constituent clans. Djambawa Marawili (pers. comm., 4 October 2007) draws an analogy between a group of connubially-linked homelands and a town, with each homeland being a 'suburb'. The spatial relationship between clans and their estates, and between clans within a connubium on neighbouring estates (see Morphy and Morphy 2006), is thus reinforced by the physical presence of settlement infrastructure. But at the same time, the Yolngu lifestyle is characterised by high levels of mobility. Short-term, localised mobility is fuelled by both social and purely logistic considerations. Only one of the Laynha homelands has a store, and so it is necessary for most homelands dwellers to go either to Nhulunbuy or Yirrkala to shop for food and other necessities. People also have to travel to meetings, for training, for medical appointments, and even on occasion further afield for such things as art exhibition openings in metropolitan centres. Ceremony, particularly in the context of funerals and boys' initiation rites, is a major and frequent cause of short-term mobility (see F. Morphy 2007a, 2007c). Visiting kin in other communities is also a factor, particularly during school holidays. People tend to be more mobile at certain times in their lives - many young adults, particularly young men who have not yet married and 'settled down', are highly mobile in the medium term. They are referred to as dhukarrpuyngu ('people of the track'), and move frequently between households and communities where they have kin. In the longer term - but here we enter the realm of speculation since no reliable research exists on the extent, trajectory and nature of outmigration - are those who are 'economic' migrants to places where there are 'real' jobs, or even medical migrants. ${ }^{15}$ If one sits at a particular homeland in any particular week, the impression can be one of constant flux and movement

\footnotetext{
${ }^{15}$ As in other parts of Indigenous Australia, kidney failure as a consequence of diabetes is unfortunately becoming common. Until very recently, there were no facilities for dialysis in Arnhem Land. Yolngu suffering from renal failure had to live semi-permanently in Darwin to avail themselves of the facilities there. There was a bucket of money from the NT Department of Health (delivered through Laynha) to support them and their families to live in Darwin, but no bucket in the Health Department's hospital budget to pay the technicians necessary to maintain a dialysis facility in Nhulunbuy Area Hospital.
} 
as vehicles and planes come and go. Yolngu are still very much 'people who move around'.

\section{Leadership in the Yolngu world}

Gurrutu continues to be the Yolngu 'governance environment' par excellence. The domain of governance is the management of relationships, both mundane and ceremonial, between groups at various levels of articulation from the very local to the regional. ${ }^{16}$

At the level of the clan, primogeniture and gender are the most important determinants of ascribed leadership status, but there are quite effective checks to the automatic ascription of power to people in powerful structural positions. Personal autonomy is highly valued and may be strongly asserted (sometimes by avoidance of situations in which the power of others can be exercised). Ultimately a 'good' leader is a person to whom other people will listen, and who can create and maintain consensus - a sense of ngayangu wanggany 'one feeling' or mulkurr wanggany 'one mind' (see F. Morphy 2007c). Thus, leadership is conferred conditionally and has to be constantly earned. It is a process rather than an ascribed position in a hierarchy, although some people do start with structural advantages. Whereas English-speakers tend to talk about the 'head' of a family or organisation, the predominant Yolngu metaphor is ngurru - 'nose, prow of canoe'. The English metaphor implies a view of a leader as the apex of a vertical hierarchy, whereas the Yolngu metaphor implies a view of a leader as someone who carries others behind him. ${ }^{17}$

On the Laynhapuy homelands, the Yolngu system of governance still operates according to these principles. It has adapted to the circumstances of small settlement life. It still depends on the same mix: 'good' leaders are those who can lead through consensus and, all things being equal, they tend to be the first-born sons of the leaders of the preceding generation. And the system is still grounded, in the sense that homelands settlements tend to cohere around the senior male members of the estate-owning clan (see Barber, forthcoming).

'Fairness', 'equality' and 'democracy', the cornerstones of 'good' governance in western liberal democracies, are not salient to this system. There is nothing 'fair' or 'equal' about male primogeniture - all people are not created equal, and leaders are not 'elected' on democratic principles. But this system has its own set of checks and balances (or mechanisms of accountability): leaders who lead

\footnotetext{
${ }^{16}$ For an extended analysis of Yolngu leadership in relationship to land, and particularly in relation to religious aspects that fall outside the scope of this paper, see Williams $(1986,1987)$.

17 The term ngurru is not generally applied to women in the context of clan leadership, but if a woman happens to be the first-born person in her generation (malamarr), and if she is a person with a strong personality, she may sometimes take on 'ngurru-like' roles. On one famous occasion in the 1970s, the female malamarr of a large clan, a formidable woman, led a party of her clansmen to do battle with another group.
} 
by consensus are constrained by the need to reproduce consensus. Disaffected 'constituents' can 'vote with their feet', withdraw their support, and align themselves with another leader (or become one themselves if they can garner the support).

At a regional level, affairs are ordered by groups of senior leaders according to the same principles. There is no fixed hierarchy or fixed membership of such groups, but once again certain individuals will be regarded as pre-eminent because of their knowledge (mundane and sacred), seniority, and/or the size and structural position of their clan within a regional system.

\section{Gender and leadership}

In Yolngu society, there is not the same strict separation of male and female domains that is found, for example, in some desert societies. Nevertheless, power relations and the expression of power are gendered. Women are not excluded from power and influence, or from positions of leadership, except in certain restricted ceremonial contexts, but they do not generally attempt to exert their authority overtly in public contexts in the same way that men do. At public meetings, men tend to sit centre stage, with the most senior men in the most central positions, and women sit on the periphery. It is mostly men who speak, but women monitor proceedings carefully, and senior women interject comments into male 'performances' or sometimes take the floor if they feel that the discussion is not going as it should. If male leaders fail to achieve the consensus of senior women, then it is unlikely that whatever decision they make will take effect.

For some time, women have been taking positions of power and authority in certain intercultural contexts, particularly education. The head teacher of the school at Yirrkala was until recently a Yolngu woman, and the head teacher at Gapuwiyak is also a Yolngu woman. At Laynha, following the recent departure of the non-Yolngu Chief Executive Officer (CEO), his successor is a Yolngu woman. $^{18}$

\section{Laynha as an intercultural zone}

In adopting a framework that privileges relative autonomy it is possible to view organisations like Laynha as sites of intercultural production, using Merlan's term in a more restricted sense. Such sites are 'border zones' (Clifford 1997) where two relatively autonomous systems meet and interact to create hybrid or intercultural forms. ${ }^{19}$ Mattingly (2006: 495) characterises such zones as places

\footnotetext{
18 Women have also become increasingly prominent as artists since the 1970s.

19 Cornell and Begay's (2004) concept of 'culture match' also addresses the idea of intercultural forms, but with an important difference. True 'culture match', as envisaged by Cornell and Begay, can only take place in a context where actors from an encapsulated society have freedom to choose, pragmatically, between alternatives. In practice, this means that the encapsulating culture refrains from using its power
} 
where 'culture emerges more vividly as a space of encounter than of enclosure ... This sort of cultural world is characterised by politically charged, difference-making exchanges among actors' (emphasis added). As Merlan rightly notes (see above), in a situation where one system is the encapsulating state and the other is a localised system of a minority group, the power relationship between the systems is unequal.

\section{The Laynha constituency: connubia and 'membership'}

Laynha's constitution, as an organisation incorporated under the NT's Associations Act, stipulates that the organisation must maintain an up-to-date list of members. The Act, as an instrument of settler society, assumes that membership of an association is a bounded category. Laynha does maintain such a list, but it is essentially an artefact of the intercultural space rather than a true reflection of the organisation's Yolngu constituency.

The region serviced by Laynha is partly a construct of the colonial past, reflecting the former sphere of influence of Yirrkala Mission. It contains (parts of) the estates of the clans of three large contemporary connubia: the Djalkiripuyngu centred around Blue Mud Bay; the Laynhapuyngu, whose clan estates stretch down the east coast and its hinterland from south of the Gove Peninsula to south of Caledon Bay; and the Miyarrkapuyngu to the west of them and to the north of the Djalkiripuyngu. There is a dynamic tension in the governance of Laynha between two connubia-the Djalkiripuyngu of Blue Mud Bay and the Laynhapuyngu, which is dominated numerically (in the context of the Laynha homelands and the Association) by the senior lineages of the large Gupa Djapu clan. ${ }^{20}$ The sources of tension are complex - Gupa Djapu at one time (still within the memory of the parents of the oldest people still now alive) were part of Djalkiripuyngu, and have moved their sphere of influence northwards, with certain lineages forging alliances through marriage with the clans of the Yirrkala

\footnotetext{
to impose particular socio-cultural forms: 'the issue of culture match is about power ... what matters for governance legitimacy and effectiveness is that the process of culture match be under Indigenous control' (Hunt and Smith 2006: 18). It could be argued that in the period of 'self-determination' such conditions obtained to some extent in Australia, but that this became less and less true during the neo-assimilationist regime of the Howard Government.

20 As with connubia, there is now a certain fixing of clan identity taking place. Gupa Djapu is a very large clan of over 350 people, all descended from a single ancestor who had over 20 wives. It is unlikely that in the past such a large clan would have continued to exist as a 'corporate' entity. Evidence from the period around missionisation (and from the memory of the oldest people still living) suggests that fission of large groups occurred, usually along lines of marriage. In these circumstances, the existing clan estate would have become two, or one of the subgroups would have taken over the clan estate of a small or extinct märi group, first in caretaker mode, but over time becoming seen as the primary owners for that country with a separate clan identity. This tendency is visible in the Gupa Djapu case, where certain lineages are more closely associated with the Laynhapuyngu connubium and other lineages with the Djalkiripuyngu or Miyarrkapuyngu, through their marriages into clans of those connubia. However, with the advent of certain fixing processes such as the written record and the introduction of clan 'surnames' the further process of fission is frozen. What we are seeing is the influence of one system on the trajectory of another.
} 
area. They are now thought of principally as Laynhapuyngu, although they have strong connections to all the connubia of the area. Today's Djalkiripuyngu, on the other hand, are the group with the least strong history of association with Yirrkala Mission. In 'mission times' many of their senior leaders and their families went south or to Groote Eylandt rather than to Yirrkala. Their return to the orbit of Yirrkala was prompted by the start of the homelands movement, which was initiated by the senior lineage of the Gupa Djapu. Today, many Gupa Djapu live at Yirrkala, and of the Yolngu office staff at the Laynha headquarters the majority are Gupa Djapu. Gupa Djapu is the only clan with more than one homeland settlement on its clan estate, and Gupa Djapu men are the senior leaders at two other settlements.

\section{The Laynha 'community'}

In geographical, organisational and political terms, Laynha fits the 'centralised hub and spokes' model described by Hunt and Smith (2006: 88, Fig. 7; reproduced here as Fig. 5.5), but with added complexities. The organisation is physically located in the 'hub' community of Yirrkala, but is not under the jurisdiction of the local council. It is in, but not institutionally part of, Yirrkala's community of governance.

\section{Fig. 5.5 The hub and spokes model}

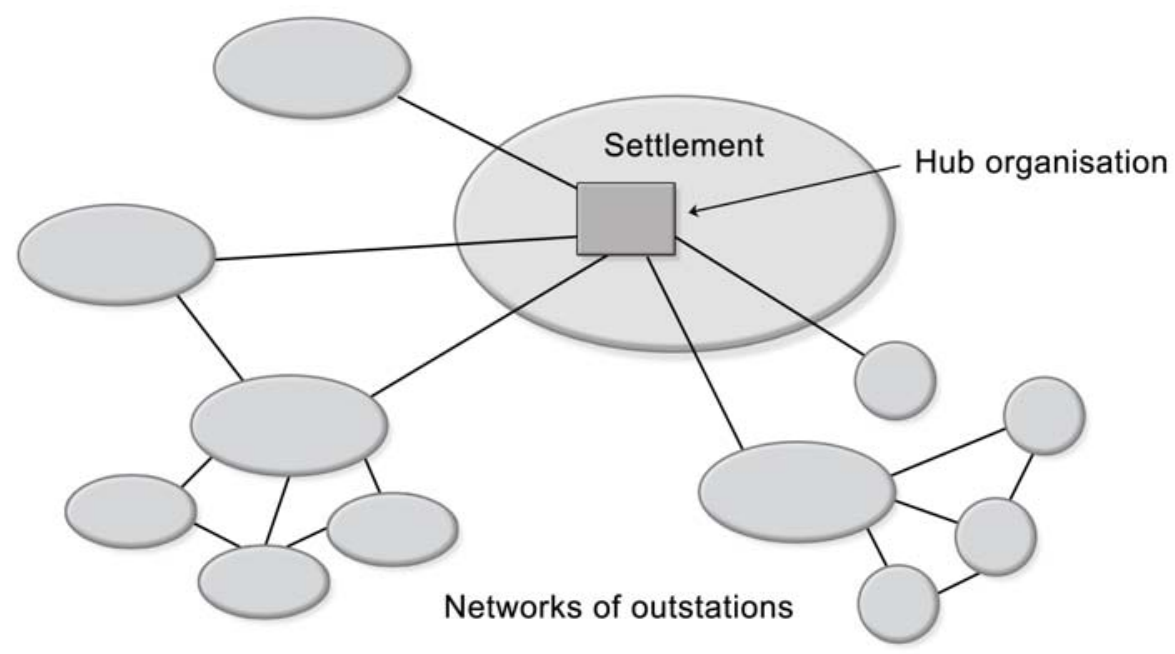

Laynha does not service a 'community', but rather a group of outlying homelands settlements. The people who live on these homelands are interlinked both with each other and with the people who live in the wider region (see Fig. 5.1), including Yirrkala, through the complex web of kinship, ceremonial and political interests described above. Although Yirrkala is the service 'hub', it is not the 'hub' of socio-political relationships for many Laynhapuy homelands dwellers. 
Many do have strong kin connections to Yirrkala, but others, particularly those who live in the southern outstations around Blue Mud Bay, are oriented as much to Groote Eylandt and/or Numbulwar, or to Gapuwiyak and its homelands. Some of the northern homelands have strong kinship and ceremonial links to the Gumatj-dominated community of Gunyangara (Ski Beach) and its homelands (one of which, Biranybirany, is physically located inside the Laynhapuy area), and/or to communities further west such as Galiwin'ku and the Marthakal homelands. This can be seen, for example, in the pattern of people's movements to funeral ceremonies in the region. Although some people reside on a long-term basis at a particular homelands community, others shift over time-sometimes in and out of the ambit of the Laynha homelands - according to particular life circumstances and their kinship connections. Some people who are considered to be Laynha members in fact reside principally at Yirrkala. They are members because their clan identity ties them to one or other of the homelands settlements.

It is therefore not a straightforward matter to define the 'membership' of the association. The notions of 'community of identity' and 'community of interest' (cf. Hunt and Smith 2006: 5) have some application, but only if these 'communities' are understood as being somewhat unbounded in nature. The notion of 'administrative community' also only fits partially. In terms of health services, Laynha services homelands that are not otherwise part of the service population, and the recently declared Laynhapuy IPA covers some homelands that are outside the Laynha service area and excludes some that are inside it. Finally, the artists of the Laynha homelands are serviced by Buku-Larrnggay Mulka at Yirrkala, which is under the umbrella of the Yirrkala Dhanbul Association. ${ }^{21}$

The 'community' that Laynha services can best be conceptualised as a nodal network (a set of localities that receive the full range of Laynha services) and a penumbrum of other homelands that are connected to the organisation in particular ways but peripheral to it in others. The lack of clear boundaries around 'membership' constitutes a 'problem' for policy makers who want to deliver services to bounded entities with sedentary populations (see F. Morphy 2007d). However, it should not be assumed a priori that lack of boundedness is a problem for Yolngu themselves, or for the governance of their organisations. Indeed, in many respects the structure of the Laynha 'community' mirrors the networked and unbounded nature of Yolngu polities of kinship. And it shares with them

\footnotetext{
${ }^{21}$ At least this was the case until the Federal Government's 'intervention' in the NT. Like many other community owned businesses in 'prescribed' communities, the future ownership of Buku-Larrnggay Mulka and its assets is currently uncertain. Art production and sale is a significant component of the local economy, with around 100 homelands artists dealing regularly with the art centre, and another 150 or so on a less regular basis (Andrew Blake, pers. comm., 21 December 2007). From time to time Laynha has contemplated starting its own art centre, but has never pursued this option. Established originally in the 1970s, Buku-Larrnggay is one of Australia's most successful Indigenous arts centres, and in face of that, setting up in local competition would make very little sense.
} 
another property - that of a relative stability over time which is not merely an emergent property of the system but a social fact. ${ }^{22}$ And if Laynha is conceptualised as a set of localities - the hub and the homelands - it shares yet another property of the Yolngu system. Whereas the localities are fixed in space, the individuals in the populations associated with them are mobile to varying degrees and over varying timescales.

\section{Leadership in the Laynha context}

Laynha's constitution currently provides for the election of a 12-person board at the Annual General Meeting (AGM). Those nominated must have a proposer and a seconder. Election is through a secret ballot of the membership, and the system is 'first past the post' - the first 12 people with the most votes are elected. ${ }^{23}$ Once elected, the board members then decide among themselves who the office holders will be for that year. On the surface, this appears to be a standard democratic process conducted according to settler notions of good governance.

In practice, because of distance and expense, it is impossible for the entire membership of Laynha to attend an AGM. A meeting is quorate if 24 members are present, and on average an AGM has an attendance between 30 and 50. Very often, there are no more than 12 people nominated, although this was not the case in 2007. The resulting composition of the board is remarkably similar over the years, with each of the major homelands having at least one member, and the largest usually having two. Those elected tend to be drawn from the ranks of middle-aged leaders. ${ }^{24}$ The distribution over the three connubia also tends to reflect their relative prominence, with the Laynhapuyngu and Djalkiripuyngu usually having roughly equal numbers of board members and the Miyarrkapuyngu having fewer than either. Within the Laynhapuyngu contingent, the Gupa Djapu usually predominate. This process is democratic, but not according to the 'one vote, one value' model that the constitution enshrines. In the hands of the Yolngu membership, what emerges is more like

\footnotetext{
${ }^{22}$ From time to time particular communities shift in and out of the orbit of Laynha membership, in a way that parallels shifts in the composition of connubia. During the fieldwork period, one large homeland that had once been a 'full' member of the Laynha constituency, but which had transferred to Marngarr following a disagreement (not with Laynha as an organisation but with the leaders of one of the clans that is central to Laynha), decided that they wanted to return to the Laynha fold. They were welcomed back, and this was a sign of the resolution of tension between the two parties. Also during this period, the Gumatj homeland of Biranybirany, which is geographically surrounded by Laynha homelands but is primarily serviced by Marngarr, decided that it would become part of the Laynhapuy IPA.

${ }_{23}$ This is the number under the current constitution, which was put in place in 2006. The board has replaced the 10-member council that operated under the previous constitution.

${ }_{24}$ Middle-aged here designates people between the ages of approximately 35 and 55. A few homelands have more elderly leaders still living, but it is rare for these people to seek nomination. Power is ostensibly delegated to the next generation.
} 
a system of proportional representation that achieves a balance between the different kin networks and regional interests of the membership.

Thus, both in terms of the membership and of the leadership structure of the organisation, Laynha conforms on paper to the 'norms' of 'good' governance as laid out in the legislative framework provided by the settler state. Yet it actually operates in a way that is heavily imbued with Yolngu principles of governance.

\section{Power, accountability and value}

This study began with quite a different research focus from that which has emerged during the course of fieldwork. As a linguistic anthropologist who had worked with Yolngu-but not with their organisations-since 1974, I was initially interested primarily in Yolngu conceptualisations of governance and how these translated into the organisational environment. I anticipated that there would be differences between Yolngu conceptualisations and those of non-Yolngu staff (see F. Morphy 2007c), and wanted to investigate how the space between these two sets of views was negotiated in the context of the organisation. Was some form of 'cultural match' (Cornell and Begay 2004) in place, and if not, was it attainable? Although I was conscious of something called the 'wider governance environment' within which the organisation sat, I did not then see it as a major focus of the research.

But it happened that my fieldwork took place during a period (2005-07) when that wider environment was undergoing a radical transformation. Early on, it became clear that the increasing pace of change in government policy and in the manner of its implementation, both at the Territory and Commonwealth levels, was putting the organisation under strain. ${ }^{25}$ The tension between Yolngu conceptualisations of the nature of the organisation and those of its government paymasters had reached a point where its causes had to be examined and addressed if the organisation was to survive. In effect, I was witnessing a struggle between the Yolngu 'world' and the state over exactly what kind of organisation Laynha is, and what it exists for.

In his introduction to Seeing Like a State, James C. Scott (1998) describes the project outlined in the epigraph to this chapter as 'the road not taken'. He came to see efforts at sedenterisation as but one type of action in the more general project of the modern state - that of making society 'legible', the better to control and administer its subject-citizens. This chapter is framed partly in terms of Scott's original, more narrowly defined research question. In the case of an Indigenous organisation whose members live 'radically uncontained' mobile lives (F. Morphy 2007d), but which is heavily dependent on funding from a

\footnotetext{
${ }^{25}$ During most of the field research period, the NT Government's plans to reorganise local government remained in a preliminary stage, and it was hard to gauge the implications for organisations like Laynha. Ultimately, they may be far-reaching, but are outside the scope of this paper.
} 
state that has in recent years become increasingly inimical to such a lifestyle, the governance of the organisation has to be seen as the site of a political struggle - rather than merely a site of engagement - between incommensurable sets of values and objectives. In such a context, 'good' or 'effective' governance is not, as it is so often portrayed, a matter to be contemplated as if it were a politically neutral matter. The question to be asked here is: when considering the governance arrangements of an organisation like Laynha, who is this governance for, and for whose good? This is partly a question about power-how it is exercised by the powerful, and resisted, circumvented or accommodated by the relatively powerless - and partly a question about value. The focus of this chapter, then, is on the struggle over value that I witnessed, rather than on the details of Laynha's governance arrangements per se.

Central to the question of 'good' governance is the notion of accountability. In this case, government, the holder of the purse strings, has much more power than the other partner in the arena-the encapsulated and locally isolated minority Indigenous population, as represented by local organisations like Laynha. Elsewhere I have argued (F. Morphy 2007c) that having a system of checks and balances - in other words a system of accountability that is bidirectional - is a universal of good governance arrangements. ${ }^{26}$

Drawing on the work of O'Donnell (1999) and Schedler (1999), Schacter (2000: 1) distinguishes 'vertical' accountability 'of the state to its citizens' from 'horizontal' accountablility 'by the state to its own public institutions of accountability'. He points out that:

Governments are more likely to bind themselves through institutions of horizontal accountability under circumstances where citizens will punish them for failing to do so. Horizontal accountability must therefore be buttressed by strong vertical accountability (Schacter 2000: 1-2; emphasis in the original).

The Howard Coalition Government, in its relationship to Australia's Indigenous peoples, began quite early on to systematically diminish their ability to hold the government to vertical account, starting with the abolition of the national representative system embodied in the Aboriginal and Torres Strait Islander Commission (ATSIC). The attrition of horizontal accountability followed inexorably, and reached its apogee when the government gained control of the Senate in 2006. Its 'National Emergency' intervention into the NT and the passing of the legislation that legitimated it were the actions of an unaccountable government - it seemed to feel no need either to address the recommendations

\footnotetext{
26 For an extended analysis of reduced political accountability in Indigenous affairs in the last two decades and its effects see Sullivan (forthcoming, 2008).
} 
of the report ${ }^{27}$ that was the purported catalyst for the intervention (Behrendt 2007: 15) or to put in place measures to evaluate its effectiveness (Hinkson 2007: 2-3).

\section{Two contrasting conceptualisations of Laynha as an organisation}

Having now set the framework for the analysis, outlined some relevant characteristics of the governance principles that Yolngu and the state bring to the intercultural space, it is now time to look at that space itself in more detail. Figures 5.6 and 5.7 attempt to capture in graphic form the differences between the state view of the organisation - or rather a particular version of the state view promulgated by a neo-assimilationist government - and the Yolngu view.

\section{The view of the neo-assimilationist state}

In late 2005, the then Minister for Indigenous Affairs, Amanda Vanstone, characterised small homelands communities as 'cultural museums' (Vanstone 2005). This trope designates Indigenous worlds as static repositories - they cannot, in this view, be a valid field of social action and value. In such a view, the Laynha homelands are merely a particular kind of (remote, expensive, 'dysfunctional') service population encompassed within the state, and Laynha is their service provider. If the ongoing existence of the 'other culture' as a system of action and value is denied, then so too, by definition, is the intercultural nature of Indigenous organisations. In Fig. 5.6, then, Laynha is shown as fully incorporated in a state system that is arranged in a vertical hierarchy.

The Howard Government did not have a coherent view of remote homelands as functioning communities, and indeed, as Fig. 5.7 suggests, it did not have a coherent view of organisations like Laynha. Following the demise of ATSIC, funding for programs had been increasingly provided by a series of mainstream departmental silos; Yolngu individuals were perceived as partible - as consumers of health care, CDEP participants, units requiring housing, and so on. Laynha is also partible, viewed by one government department as an Indigenous Housing Organisation, by another as a CDEP provider under contract, by another as a local heath service provider, and by yet another as the management support for an IPA. This is not a particularly unusual circumstance in the government machinery of large nation-states like Australia. Settler Australian citizens are accustomed to such partibility and compartmentalisation, viewing them as

\footnotetext{
27 This was the Little Children Are Sacred report, of the Northern Territory Board of Inquiry into the Protection of Aboriginal Children from Sexual Abuse (Anderson and Wild 2007). Among other things the report strongly advocates a detailed process of consultation with affected communities and individuals in addressing the problem of abuse, whereas the intervention took place with no prior consultation with those affected.
} 
'normal' (if sometimes regrettable) features of governance arrangements. The failure to recognise the Yolngu 'world' as an encapsulated social field, and the failure to see that Laynha is a complex organisation with multiple functions that interrelate to support its material base, is what is at issue here. ${ }^{28}$

\section{Fig. 5.6 The intercultural space from the state's point of view}

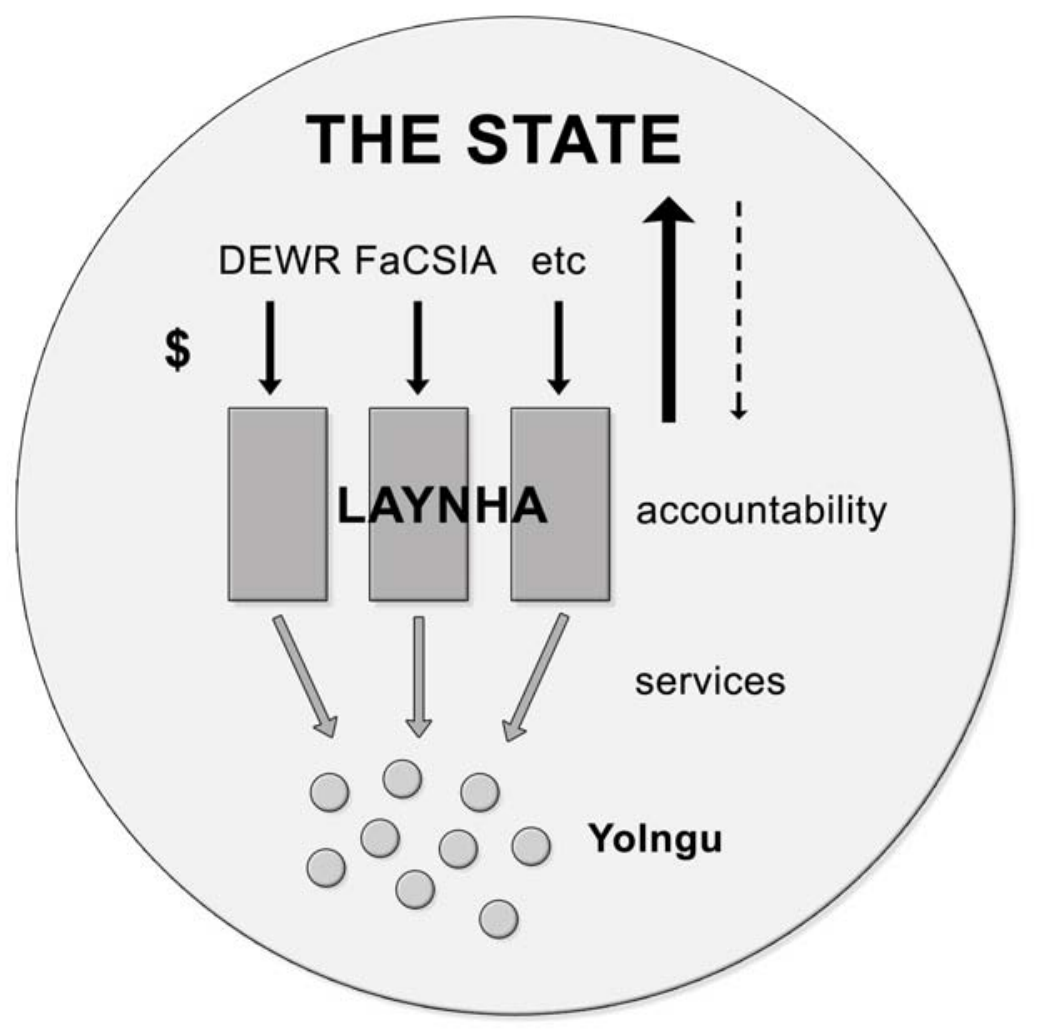

\footnotetext{
28 It could be argued that the Howard Government did attempt in various ways to take a more 'holistic' approach to Indigenous affairs. They instituted the Council of Australian Governments (COAG) trials, they set up Indigenous Coordination Centres (ICC) as 'one-stop shops', and instituted the Shared Responsibility Agreement regime. None of these initiatives has been successful, however. The failure of the COAG trials is well-documented (in a series of evaluation reports that the government failed to release for many months; see Department of Families, Housing, Community Services and Indigenous Affairs (FaHCSIA) website at <http://www.facsia.gov.au/internet/facsinternet.nsf/indigenous/ publications.htm $>$ ). The shortcomings of the ICCs lie, ironically, in their localness. Like the organisations with which they interact, they are small and distant from the centre of power. Many individual public servants who work in ICCs do have good local knowledge and an understanding of the complex role of organisations like Laynha. But their own role is to act as conduits for (and enforcers of) the policies of central government. Because of the power of the silos at the centre it is also often not possible for the ICC to act as a 'one-stop shop'. Individual public servants are accountable to their department first and to the ideal of 'whole of government' second (see Dillon and Westbury 2007: 60).
} 
Theoretically, in such a model accountability goes both ways, but in practice there is a great deal of upward accountability and very little in the other direction. This is a function of the power relations that obtain between the small, local, funding-dependent organisation and the national state as paymaster. Upward accountability is especially burdensome because of the fractured way in which funding is delivered. Because government has no coherent overview of the local organisation, it fails to acknowledge the level of the burdens that it imposes, and fails to understand, or is indifferent to, the consequences for the organisation of abrupt and unsignalled changes in policy. ${ }^{29}$

Because government has no clear view of the Yolngu system and of accountability structures within that system, and no clear view of the organisation as an intercultural institution where different systems of accountability have to be reconciled, it also has no clear view of the burdens of downward accountability that the organisation sustains with respect to its constituency. When 'training' for governance is provided to Yolngu board members it is mostly about helping them to be upwardly accountable within the framework of government requirements (F. Morphy 2007c). To government, a 'good' organisation is a compliant organisation that delivers programs according to government guidelines on budget and on time. To the extent that the intercultural nature of the organisation is recognised at all, it is perceived as a problem, as bits of 'museum culture' that keep getting in the way of 'good' governance.

\section{The Yolngu view, 2005}

The first point of contrast between the Yolngu view and that of the government and its agencies, a point not captured in Fig. 5.7, is that for the Yolngu, Laynha has a history, and it is part of their history. It has been a constant in their institutional landscape for over 20 years. ${ }^{30}$ In the years of 'self-determination', Laynha was felt to be unambiguously a Yolngu organisation. As well as having a Yolngu council, there was a tradition of having a Yolngu manager. There was

\footnotetext{
29 A classic example of this towards the end of the Howard era was the summary and unsignalled banning of kava imports, removing more or less at a stroke Laynha's major source of discretionary income. The Federal Government was either indifferent to or ignorant of the consequences, not only for Laynha as an organisation but for the homelands that depend for the moment on the continuing existence of Laynha for services and infrastructure. The desirability of kava use is not the issue here; rather, it is the manner and the timing of the ban.

${ }^{30}$ In the past, the public service allowed and even encouraged certain of their staff to specialise in areas like Indigenous affairs, and some people developed detailed and long term local knowledge of particular regions as a result. There are ex-public servants who have an understanding of the history of organisations like Laynha, and some of them rose to senior positions, taking that knowledge with them to the centre. However, very few of them are there now, and the younger generations operate in a very different public service culture, where accumulation of such expertise and long-term association with particular regions is neither encouraged nor, it seems, particularly valued. As Dillon and Westbury (2007: 61) state: 'government disengagement has meant that over the last thirty years, there has been a significant diminution in the intellectual capital available within government to implement programs effectively in remote Australia'.
} 
usually a non-Yolngu second-in-command who managed day-to-day business and also the interface with funding agencies. In Fig. 5.7, the state is represented as a black box to reflect the general level of Laynha members' knowledge about and interest in the sources of Laynha funding. The 'upwards accountability' arrow is much less prominent than in Fig. 5.6, and originates in an underspecified zone of the oval representing the organisation, signalling that the Yolngu membership, including the council members, did not have a clear view of the burden of accountability demanded by the state, nor of the mechanisms of accountability.

\section{Fig. 5.7 The intercultural space from the Yolngu point of view}

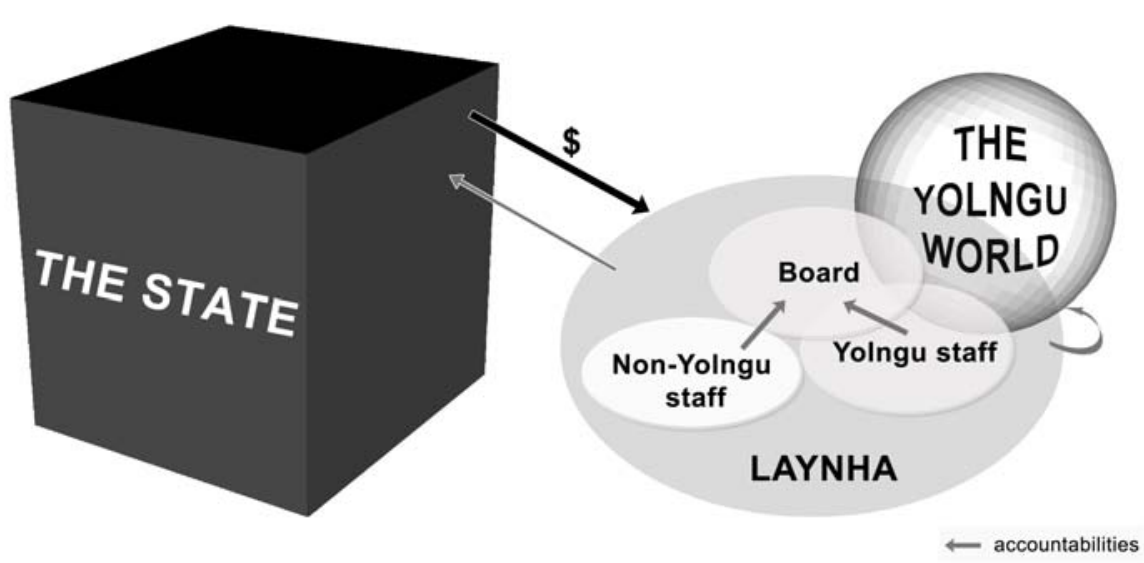

In the post ATSIC period, the membership of the organisation, including its council, continued to hold the view of Laynha as 'their' organisation, even as the policy ground began to shift under their feet. This is represented in Fig. 5.7 by the lack of overlap between the state and Laynha. The question is, why had they not noticed or understood the implications of 'grant creep', whereby Laynha now depended for its continuing existence on the state?

By and large in this period, particularly in the days of ATSIC, government was broadly supportive of the aims of organisations like Laynha, and the homelands communities that they represented and serviced. The membership could take for granted the continuing existence of their homelands, Laynha, and CDEP, and they did. One might think at first glance that in its governance arrangements Laynha achieved a kind of cultural match in this period. It complied with the conditions of its funding to the extent that it did not attract unfavourable attention to itself in the relatively benign wider governance environment. It grew and developed in a relatively organic way, with response to contingencies rather than long-term planning as the main driver of change. It did not have a linear hierarchy of management or tightly demarcated areas of responsibility (with certain exceptions - health and Laynha Air were clearly separated from 
the rest of the functions of the organisation), and the decision-making processes of the council (and later the board) were characterised by fluidity and open-endedness. These characteristics are represented in Fig. 5.7 by a set of overlapping ovals (the board, and the Yolngu and non-Yolngu staff of the organisation) that are in no clear structural relationship to one another with respect to the governance of the organisation. In one sense, this is not surprising, because they do not represent its governance structure per se, but rather the Yolngu 'two worlds' view of Laynha as an intercultural space. Laynha is conceptualised as a zone between the two 'worlds', with different sets of actors positioned along a continuum of inclusion and exclusion. The board, and the Yolngu staff members overlap with the Yolngu 'world' (and with each other), and the non-Yolngu staff sit between the periphery of that world and the state.

In such a conceptualisation there is an implicit general principle of governance: it is the role of Yolngu to manage relations with the Yolngu world and the role of non-Yolngu staff to manage relations with the state, for the benefit of Yolngu. While the state holds a partible view of the organisation's functions, the Yolngu view is holistic. Yolngu living on the homelands do not have a clear appreciation of funding streams and their associated conditions and constraints. In the past, Laynha has frequently used its income from kava to supplement government programs, for instance by providing assistance to members to act as escorts for sick relatives, and by contributions to the funding of capital projects such as the building of the ranger station at Yilpara. It has also initiated its own projects, such as building and equipping offices on the homelands. The power and water systems on the homelands have also been substantially funded from kava income. Laynha's contributions from kava income to the expenses of funerals and other ceremonies have had a significant impact on the trajectory of Yolngu ceremonial life, and on the process of intergenerational cultural transmission. ${ }^{31}$ Such aspects of the organisation's role are not given any kind of official recognition by the state.

\section{Culture mismatch?}

In 2005, at the beginning of the research period, the differences between these two conceptualisations of the organisation were taking their toll on the governance of the organisation and on the morale of its staff. Council was not truly in control. The locus of power and decision-making was with certain non-Yolngu members of staff who mediated the flow of information between the organisation and its members (as represented by the council), and between the organisation and the state. Other non-Yolngu staff members were uneasy about the lack of hierarchy and the lack of defined areas of delegated 31 For a fuller account of the uses of kava income see Laynhapuy Homelands Association Inc. (2007:
23-5). 
responsibility, and the ad hoc nature of much decision-making. There were chronic points of tension between non-Yolngu staff and both Yolngu staff and members - over the 'proper' use of Laynha vehicles and perceived inequities in the distribution of staff time and Laynha resources, to name but two. It was an organisation not fully attuned to the wider governance environment and how its role was viewed in that environment, and it was ill-prepared for the neo-assimilationist turn in government policy.

\section{Meeting the neo-assimilationist challenge, 2005-07}

In the last years of the Howard Government, Laynha and other organisations of its kind found themselves thrust into crisis mode. There was a lot of change during this period. Some of it was pre-emptive on the part of the organisation, in anticipation of the need to prepare itself for engagement with an increasingly interventionist regime. Some of it was enforced-to resist would have meant loss of funding and threatened the viability of the organisation.

The catalyst for change was the transfer of the CDEP program from ATSIC to the Department of Employment and Workplace Relations (DEWR). In 2005-06, changes to the CDEP program were put in place from the centre, which appeared to take no account of the realities of the local economies of, and the state of the labour market in, remote Aboriginal Australia, nor of the 'job-readiness' of the majority of the working-age Indigenous population. Laynha was told that it had 12 months to create one business and exit 15 individuals off CDEP and into 'real' employment. By dint of transferring some Yolngu staff of the organisation off CDEP wages onto 'real' wages paid from Laynha's discretionary income, the organisation almost succeeded in meeting the 'employment' target, but clearly this was not a sustainable strategy over the longer term. The organisation did not have the capacity or the resources to start a business within a 12-month timeframe, and there was no coherent support from government to help them achieve this. It was almost as if government was wanting organisations like Laynha to fail, and not surprisingly, Laynha was told at the end of the year that it had performed 'poorly'. For the next year it was told that it had to employ a CDEP co-ordinator as a condition of receiving the Laynha CDEP contract and that it had to undertake a capacity building plan against which its achievements would be measured as a condition for future funding. It was set another (higher) job creation target, and told it had to create two businesses. The CDEP guidelines for 2006-07 also had major implications, potentially, for other aspects of the organisation's governance. Under '6.1.1 Governance', the following appeared:

To ensure commercial effectiveness CDEP organisations are also encouraged to have Board or Governing Committee members who have accounting, legal and/or business qualifications ... As an initial step DEWR requests that wherever possible CDEP organisations work towards a goal of no more than 50 per cent of their Board or Governing Committee 
be [sic] active participants, supervisors, coordinators or managers of the organisation by the end of 2006-07 (DEWR 2006).

Or, in other words, by the end of the year the Laynha council would, in the government's mind, be replaced by a board with 50 per cent non-Yolngu membership.

During the next year, Laynha commissioned a review of its structure (Tallegalla Consultants 2006), appointed a CDEP co-ordinator and, for the first time in its history as an organisation, a non-Yolngu CEO who was charged with improving the internal governance of the organisation. It also revamped its executive arrangements, including providing a stipend for the Chair of the newly constituted board of directors so that this position was no longer filled by a CDEP participant. All this was not achieved without internal struggle. Appointing a non-Yolngu CEO required a substantial change to the culture of the organisation, and the new CDEP arrangements, once the co-ordinator was in place, began to have perceptible effects that were not always welcomed by participants. For example, the continuing requirement to create jobs quickly meant a continuing emphasis on jobs at Yirrkala rather than on the homelands, and the stricter reporting requirements for CDEP participants began to have an effect on people's abilities to fulfil their cultural obligations. The Yolngu board found themselves in the position of having to participate in social engineering, for example by reducing financial and practical support for funeral ceremonies, thus adding a new dimension to Yolngu 'politics'. ${ }^{32}$ And the organisation was to receive two further body blows: the summary banning of kava on which it depended for valuable discretionary income, and the summary abolition of CDEP, now fortunately averted.

All this was taking place in a context of accelerating change in Commonwealth Government policy, in which the very existence of homelands, and therefore of the organisations that support them, began to be at issue. Also, as the NT Government's planning for the new shire structure began to gather pace, questions over the future role of organisations like Laynha in the delivery of services have begun to be raised (but not as yet answered). Thus, despite making great efforts to comply with government requirements, to the extent of compromising the Yolngu view of the role of Laynha as an organisation, at the time of writing the future of the organisation seems very uncertain.

The strains placed on the staff of the organisation in the last two years have been very considerable. Staff vary in their perceptions of their role, and these

\footnotetext{
32 This question is examined in detail in Morphy and Morphy (2007). For very different reasons, both DEWR and elements of the local Yolngu leadership consider the hypermobility occasioned by funerals, and the amount of people's time that they occupy, to be problematic. So, in a sense the government's new strictures provided certain Yolngu leaders with an opportunity to make changes that would have been difficult to implement otherwise.
} 
differences have been exacerbated by the increasing ambiguity of Laynha's role. Few of the non-Yolngu staff see the two 'worlds' as separate in the way that Yolngu do. Some subscribe to a government-like view of the position of the organisation. Others struggle to maintain a sense that they are working in a Yolngu organisation for the Yolngu members, while being conscious that they are implementing policies that are inimical to varying degrees to the Yolngu world view.

\section{Conclusion: towards a negotiated and empowering system of governance in the intercultural space}

If Laynha is to survive as an organisation, it is clear that it is going to have to change its roles and functions - yet again. Until the new shire arrangements are in place, it will be difficult to know precisely what the reactive changes will have to be. But organisations like Laynha ought to survive, for two reasons. First, they are a locus of representation for homelands Yolngu in the interface with the encapsulating society. Second, until governments can improve their own capacity, this is the only level in the governance structure of remote Australia where a view of Yolngu society as a complex, functioning whole is consistently maintained. Given the right assistance and support, organisations like Laynha can institute proactive change and become the drivers of sustainable economic development in their constituent communities - in an economy that envisions more options for Yolngu than migration to unskilled or semi-skilled jobs in towns and on mine sites (at best), or unemployment and fringe-camp dwelling (at worst).

The Yolngu people who are the constituents of Laynha, and for whose benefit the organisation exists, bring to their interactions with the Australian settler state a set of local and culturally distinctive ideas about what constitutes 'good governance' (F. Morphy 2007c). As an institution of the 'intercultural space' or 'border zone', Laynha is a site of contestation over value, where Yolngu and settler Australian (represented by state bureaucratic) ideas of 'good governance' presently meet head on. This is often an uncomfortable - and sometimes untenable - place to be, for both Yolngu and non-Yolngu staff of the organisation, and it is not conducive to effective governance arrangements. The way in which the settler state has recently sought to exercise power and authority over Aboriginal people and their organisations has exacerbated this struggle over value, and it is wasteful of time and energy, to the extent that 'good' governance is compromised-not only the governance of organisations but also of government itself.

Sidestepping the struggle over value - over what constitutes 'good' governance - involves two distinct steps. First, both the state and the Yolngu have to come to an understanding that there are two systems of value at play in the intercultural space, and that both systems are complex. 
Yolngu principles of governance tend towards the production of fluid, open-ended situations. 'Boundaries are to cross' (Williams 1982), in that nearly everything is potentially negotiable and subject to iterative negotiation, so long as correct principles are followed and values adhered to. Although there are ascribed aspects to the creation of leaders, leadership is defined and maintained through process rather than fixed hierarchies of authority. There are separations of duties and responsibilities, as in the roles of wänga-watangu ('land owner') and djunggayarr ('manager') with respect to clan estates, but there is no absolute separation of powers. Actors are always socially positioned in a particular social context, even when taking mediating stances in a particular interaction (e.g. in dispute settlement). Indeed, not being so positioned is viewed negatively. One of the worst things a person can say of a fellow Yolngu is that they are gurrutumiriw ('self-interested', lit. '[behaving] without [regard to] kin'). All of these characteristics of the Yolngu polity and its principles of governance are antithetical to the western ideal of 'good' governance, with its emphasis on boundedness and closed categories, fixed hierarchies, planning, risk management, and 'neutral' professionalism.

The Yolngu system is founded in a view of the world that sees its ancestral underpinnings as eternal and unchanging, but life on the surface, in the everyday, as governed by contingency. In such a world planning happens, but more often than not contingencies will intervene to disrupt the plans. Adaptability, fluidity and creative negotiation are seen as valuable and necessary in such a world, and are valued as integral to planning. A border zone can be viewed as a space of contestation, but also as a space for creativity in which complex contingencies are at play. And some of those contingencies, it seems, include abrupt and un-negotiated shifts in government policy.

In the world view of the governments and bureaucrats of western state systems, on the other hand, contingency is seen as something that can be contained through planning - one can 'manage risk' and even plan for contingencies, after all. The illusion of control is achieved by setting up bounded categories and controlling the enclosed space (either physical or conceptual). If that fails, if what is contained threatens to overflow the boundary, one simply shifts the boundary ('reviews the plan'). Most of the time this is such a 'normal' process that it goes unremarked - indeed it is the very stuff of governance. But sometimes the shift is very noticeable, and momentarily the solidity of the boundary disappears. When that happens, one speaks of 'moving the goalposts' or, more cerebrally, of a 'paradigm shift'.

Other evidence of this worldview is seen in the power of silos-government departments that, in effect, create arbitrary boundaries that cut across the continuities of everyday life. In this context it is interesting that the state seems to have difficulty in conceptualising where Indigenous people fit. For many 
years they were treated as a bounded category, and given their own department. Sometimes they were bundled with 'culture' (tourism and the arts), sometimes with the 'other' (immigration and ethnic affairs). Today it seems they are partible just like everyone else, although also categorised through the continuing existence of Indigenous-specific programs or sub-offices within the mainstream departments. Added to this is a fundamental lack of clarity over which 'bits' of Indigenous affairs are the Commonwealth's responsibility, and which the NT's. It is little wonder that many Indigenous people experience the workings of government as impenetrable and essentially contingent and arbitrary in nature. Compartmentalism may be the only way in which such a large and complex system as a state can be managed. The problem comes with the attribution of value - this may be an effective worldview for its purposes, but is it good in some absolute moral sense and therefore always desirable? If so, it would be an effective view in all circumstances, and it would appear that this is not the case. For example, in such a view a border zone is an anomalous space. Where does it belong? Is it in this container or that one? Or does it somehow complexify the boundary, thus causing a 'problem' for governance? These questions and this problem are of the world view's making, not properties of the boundary zone in itself, for it is possible to take a very different view - the Yolngu view. It is also arguably a very ineffective view at the local level, since it results in very small communities and very small organisations having to bear onerous burdens of accountability, and deal constantly with the consequences of uncoordinated directives and actions from the centre.

Systems of value are just that - systems - not simply collections of ideas thrown together in some random and arbitrary fashion. For the moment, agents of the state seem blind to the Yolngu system, seeing Aboriginal people as having 'gaps' in their 'capabilities', as half-full vessels that can be filled by somehow pouring western ideas about governance in on top of what is already there (or in the neo-assimilationist version, by tipping out the current contents and replacing them wholesale, holding the vessels under state control until the process is complete and they are fit to govern themselves). Government agencies and trainers in 'capacity building' - consciously or unconsciously-constantly counterpose settler Australian notions of 'good governance' to a 'deficit' view of Aboriginal modes of governance.

While this remains the case, they will always meet with resistance or avoidance - whether conscious or unconscious - from Yolngu. For few Yolngu are likely to respond positively to a view which holds that the Yolngu way of doing things and the Yolngu system of value are deficient. The Yolngu system is not going to go away, and people are not vessels that can be emptied of one set of ideas and values and refilled with another, at least not without taking 
measures that are unacceptable in a liberal democracy. ${ }^{33}$ Moreover, as I have argued elsewhere (F. Morphy 2007c), to the extent that Yolngu have a theory of the value system of the encapsulating society, they do not particularly like what they see. In their view, that is the deficient system.

Having recognised that different systems can and do exist, the next step is to come to an agreement in principle to respect difference rather than viewing it as deficit - and this applies to both parties. Respect involves a suspension of the attribution of positive value to one system but not another. A respectful, informed and honest debate about pragmatics can then follow-what are the local goals in sight, whose goals are they, and what are the most effective (as opposed to 'best') strategies to achieve them in a negotiated space between the two 'worlds'. Where the two systems seem incommensurable, what compromises are possible that will best help to achieve the intended goals? This is, in fact, a debate about cultural match, where both parties - not just the weaker party - are willing to consider making changes to their way of doing things. The willingness and capacity of government is as much at issue here as the 'capacity' of Indigenous people and their organisations, for it involves a radical change in perspective, in which Indigenous peoples' local aspirations and goals take precedence over the state's impulse to socially engineer Indigenous lives from the centre, 'for their own good'.

\section{Acknowledgements}

My first and most important debt is to the board and staff of Laynhapuy Homelands Association, past and present, for allowing me to undertake the governance study during what turned out to be a rather tumultuous period in the organisation's long history. It has been a privilege to work with them, and I hope that I have contributed something positive in return. My especial thanks to Sally Wagg for her generous hospitality in giving me a home away from home on so many occasions. I thank Janet Hunt, Howard Morphy, Rebecca Morphy and two anonymous reviewers for their constructive comments on various drafts of this chapter. Any remaining errors of fact and interpretation are my responsibility.

\section{References}

Anderson, P. and Wild, R. 2007. Ampe Akelyernemane Meke Mekarle-Little Children Are Sacred, Report of the Northern Territory Board of Inquiry into the Protection of Aboriginal Children from Sexual Abuse, Report to

\footnotetext{
33 Such as, for example, removing children from their parents on the basis of their 'race', or instituting dormitory systems where children and parents have very limited access to one another, and the children are punished for speaking their own language. A more current example is the quarantining of people's welfare income on the basis of race in the NT.
} 
the Northern Territory Government, Darwin, available at $<$ http://www.nt.gov.au/dcm/inquirysaac/>

Attwood, B. 2003. Rights for Aborigines, Allen \& Unwin, Sydney.

Barber, M. forthcoming. 'A place to rest: dying, residence, and community stability in remote Arnhem Land', in M. Tonkinson, Y. Musharbash, K. Glaskin and V. Burbank (eds), Dealing with Death: Essays on Funerals and Mourning in Indigenous Australia, Ashgate, London.

Barnes, J. 1967. 'Inquest on the Murngin', Royal Anthropological Institute Occasional Paper No. 26, Royal Anthropological Institute, London.

Behrendt, L. 2007. 'The emergency we had to have', in J. Altman and M. Hinkson (eds), Coercive Reconciliation: Stabilise, Normalise, Exit Aboriginal Australia, Arena Publications Association, North Carlton.

Berndt, R. M. 1951. Gunapipi, Cheshire, Melbourne.

1952. Djanggawul, Routledge and Keegan Paul, London.

-1962. An Adjustment Movement in Arnhem Land, Mouton, Paris.

-and Berndt, C. 1954. Arnhem Land, its History and its People, Cheshire, Melbourne.

Clifford, J. 1997. Routes: Travel and Translation in the Twentieth Century, Harvard University Press, Cambridge, MA.

Cornell, S. and Begay, M. 2004. 'What is cultural match and why is it so important? Lessons from 14 years of the Harvard Project', Paper presented at the Building Effective Governance conference, Jabiru, NT, 5-7 November 2004.

Cowlishaw, G. 1988. Black, White or Brindle, Cambridge University Press, Melbourne.

Department of Employment and Workplace Relations (DEWR) 2006. CDEP Guidelines 2006-07: Community Development Employment Projects (CDEP) Program, DEWR, Canberra.

Dewar, M. 1992. The 'Black War' in Arnhem Land: Missionaries and the Yolngu 1908-1940, North Australia Research Unit, ANU, Darwin.

Dillon, M. C. and Westbury, N. D. 2007. Beyond Humbug: Transforming Government Engagement with Indigenous Australia, Seaview Press, West Lakes, SA.

Egan, T. 1996. A Justice All Their Own: the Caledon Bay and Woodah Island Killings 1932-1933, Melbourne University Press, Melbourne. 
Hinkson, M. 2007. 'Introduction: in the name of the child', in J. Altman and M. Hinkson (eds), Coercive Reconciliation: Stabilise, Normalise, Exit Aboriginal Australia, Arena Publications Association, North Carlton.

Hughes, H. 2007. Lands of Shame: Aboriginal and Torres Strait Islander 'Homelands' in Transition, The Centre for Independent Studies, St Leonards, NSW.

Hunt, J. and Smith, D. 2006. 'Building Indigenous community governance in Australia: preliminary research findings', CAEPR Working Paper No. 31, CAEPR, ANU, Canberra.

Keen, I. 1994. Knowledge and Secrecy in an Aboriginal Religion: Yolngu of North-East Arnhem Land, Clarendon Press, Oxford.

2003. Aboriginal Economy and Society on the Threshold of Colonisation, Oxford University Press, Melbourne.

-2006. 'Ancestors, magic, and exchange in Yolngu doctrines: extensions of the person in time and space', Journal of the Royal Anthropological Institute, 12 (3): 515-30.

Kleinert, S. and Neale, M. (eds) 2000. The Oxford Companion to Aboriginal Art and Culture, Oxford University Press, Melbourne.

Laynhapuy Homelands Association Inc. 2007. Submission to Senate Standing Committee on Legal and Constitutional Affairs Inquiry into the Appropriation (Northern Territory National Emergency Response) Bill (No. 2) 2007-2008, Laynhapuy Homelands Association Inc., Yirrkala, NT.

Macgowan, F. 2007. Melodies of Mourning: Music and Emotion in Northern Australia, James Curry Publishers, Oxford.

Maddock, K. 1970. 'Rethinking the Murngin problem: a review article', Oceania, 41: 77-87.

Mattingly, C. 2006. 'Pocahontas goes to the clinic: popular culture as lingua franca in a cultural borderland', American Anthropologist, 108 (3): 494-501.

Merlan, F. 1998. Caging the Rainbow: Places, Politics, and Aborigines in a North Australian Town, University of Hawai'i Press, Honolulu.

Morphy, F. 2007a. 'Mobility and its consequences: the 2006 enumeration in the north-east Arnhem Land region', in F. Morphy (ed.), Agency, Contingency and Census Process: Observations of the 2006 Indigenous Enumeration Strategy in Remote Aboriginal Australia, CAEPR Research Monograph No. 28, ANU E Press, Canberra. 
2007b. 'Performing law: the Yolngu of Blue Mud Bay meet the native title process', in B. R. Smith and F. Morphy (eds), The Social Effects of Native Title: Recognition, Translation, Coexistence, CAEPR Research Monograph No. 27, ANU E Press, Canberra.

-2007c. 'The language of governance in a cross-cultural context: what can and can't be translated', Ngiya: Talk the Law, 1: 93-102.

2007d. "Uncontained subjects: "population" and "household" in remote Aboriginal Australia', Journal of Population Research, 24 (2): 163-84.

— and Marika, W. 2005. 'Laynhapuy IPA and Yirralka Ranger Program: a new initiative for a venerable homelands association', Community Governance, 1 (4): 1-2, Occasional newsletter of the ICGP, CAEPR, ANU, Canberra.

— and Morphy, H. 2007. "'Soon we will be spending all our time at funerals": Yolngu mortuary rituals in a time of constant change', Paper presented at the 106th Annual Meeting of the American Anthropological Association, Difference, (In)equality and Justice, 28 November-2 December, Washington, D.C. (In preparation for publication in 2008).

Morphy, H. 1984. Journey to the Crocodile's Nest, Australian Institute of Aboriginal Studies, Canberra.

1991. Ancestral Connections: Art and an Aboriginal System of Knowledge, University of Chicago Press, Chicago.

2002. 'Thomson, Donald Finlay Fergusson (1901-1970)', Australian Dictionary of Biography, 16: 385-7.

2003. An Anthropological Report on the Yolngu People of Blue Mud Bay, in Relation to Their Claim to Native Title in the Land and Sea, Unpublished draft report prepared at the instruction of the Northern land Council, December 2003, Northern Land Council, Darwin.

-2007. Becoming Art: Exploring Cross-Cultural Categories, Berg, Oxford.

— and Morphy, F. 1984. 'The myths of Ngalakan history', Man, 19 (3): 459-78.

— and 2006. 'Tasting the waters: discriminating identities in the waters of Blue Mud Bay', Journal of Material Culture, 11 (1-2): 67-85.

O'Donnell, G. 1999. 'Horizontal accountability in new democracies', in A. Schedler, L. Diamond and M. F. Plattner (eds), The Self-Restraining State: Power and Accountability in the New Democracies, Lynne Rienner Publishers, Boulder.

Peterson, N. (in collaboration with J. Long) 1986. Aboriginal Territorial Organization: a Band Perspective, Oceania Monograph No. 30, University of Sydney, Sydney. 
Reid, J. 1983. Sorcerers and Healing Spirits: Continuity and Change in an Aboriginal Medical System, Australian National University Press, Canberra.

Sahlins, M. 1993. 'Goodbye to tristes tropes: ethnography in the context of modern world history', Journal of Modern History, 65: 1-25.

Schacter, M. 2000. 'When accountability fails: a framework for diagnosis and action', Policy Brief No. 9, Institute on Governance, Ottawa.

Schebeck, B. 2001. Dialect and Social Groupings in Northeast Arnheim [sic] Land, Lincom Europa, Munich.

Schedler, A. 1999. 'Restraining the state: conflicts and agents of accountability', in A. Schedler, L. Diamond and M. F. Plattner (eds), The Self-Restraining State: Power and Accountability in the New Democracies, Lynne Rienner Publishers, Boulder.

Scott, J. C. 1998. Seeing Like a State: How Certain Schemes to Improve the Human Condition Have Failed, Yale University Press, New Haven.

Shapiro, W. 1981. Miwuyt Marriage: the Cultural Anthropology of Affinity in Northeast Arnhem Land, ISHI, Philadelphia.

Sullivan, P. Forthcoming 2008. 'Reciprocal accountability: assessing the accountability environment in Australian Aboriginal affairs policy', International Journal of Public Sector Management, 21.

Tallegalla Consultants. 2006. A New Direction for Laynha: a Report on a Review of the Organisation, Tallegalla Consultants Pty Ltd, Brisbane.

Tamisari, F. 1998. 'Body, vision and movement: in the footprints of the ancestors', Oceania, 68: 249-70.

Thomson, D. F. 1949. Economic Structure and the Ceremonial Exchange Cycle in Arnhem Land, Macmillan, Melbourne.

2006. Donald Thomson in Arnhem Land (2nd edn, compiled and introduced by N. Peterson), Melbourne University Press, Melbourne.

Vanstone, A. The Hon. 2005. 'Beyond conspicuous compassion: Indigenous Australians deserve more than good intentions', Address as Minister for Immigration and Multicultural and Indigenous Affairs to the Australia and New Zealand School of Government, 7 December, ANU, Canberra.

Warner, W. L. 1958. A Black Civilization, Harper and Row, Chicago.

Wells, E. 1982. Reward and Punishment in Arnhem Land 1962-1963, Australian Institute of Aboriginal Studies, Canberra.

Williams, N. M. 1982. 'A boundary is to cross: observations on Yolngu boundaries and permission', in N. M. Williams and E. S. Hunn (eds), Resource 
Managers: North American and Australian Hunter-Gatherers, Australian Institute of Aboriginal Studies Press, Canberra.

1986. The Yolngu and Their Land: A System of Land Tenure and Its Fight for Recognition, Australian Institute of Aboriginal Studies Press, Canberra.

1987. Two Laws: Managing Disputes in a Contemporary Aboriginal

Community, Australian Institute of Aboriginal Studies Press, Canberra. 